\title{
An analysis of the risks and benefits of beef intensification
}

\author{
GRAEME OGLE ${ }^{1}$ and PHILIP TITHER ${ }^{2}$ \\ ${ }^{1}$ AgResearch Ruakura, Private Bag 3123, Hamilton \\ ${ }^{2}$ AgFIRST Consultants Hawke's Bay Ltd, PO Box 1261, Hastings \\ ogleg@agresearch.cri.nz
}

\section{Abstract}

Dairy beef enterprises are an intensification option for traditional sheep and beef businesses. Intensification largely refers to lifting soil fertility, the establishment of internal fencing and associated water supply, so that forage can be allocated with increasing precision. This precision enables higher stocking rates as a result of increasing pasture production, pasture quality, and intake leading to greater production of beef.

Two beef finishing systems were compared; one a traditional system and the other a Technosystem. Using average parameter analyses, intensification was shown to pay at market returns of $\$ 2.50 / \mathrm{kg}$ of carcass weight under the production assumptions we used. The Technosystem showed significant returns on investment lifting the return on total capital invested in the farm business from $4.9 \%$ in a traditional system to $8 \%$.

We used two software programs; RANGEPACK HerdEcon and Stockpol ${ }^{\mathrm{TM}}$ to assess the risks a farmer would face when converting to a Technosystem. The two risks assessed were the variable climate of the East Coast and market prices. While these parameters vary considerably, the probability of doing better than the traditional system is high $(84.7 \%)$. This declined rapidly if final stocking rates were less than 4 bulls per hectare with the probability of doing better reducing to $58 \%$ at 3.5 bulls per hectare. We also showed that the variability in cash surpluses is reduced by development with the coeffiecient of variation for the traditional system at $126 \%$ compared with the Technosystem of $95 \%$. Variability does have a moderate effect on reducing overall profitability $(13.4 \%)$, most of which $(9.3 \%)$ is caused by markets rather than climate. Our conclusion is that beef intensification provides a reliable means of increasing net worth and cash surpluses.

Keywords: beef intensification, bull finishing, climatic variability, financial analysis, price variability, risk, Technosystems

\section{Introduction}

The beef industry has experienced wildly fluctuating market prices in the past two decades. This questions the merits of intensifying beef enterprises, as the outlay for more stock, fencing, water supply and soil nutrients raises the fear of reducing financial viability. This is reinforced in summer dry areas such as the East Coast of the North Island where unreliable rainfall can compound mistakes made. We have assessed the magnitude of the financial benefits and the associated risks of intensifying under these conditions.

We looked at two systems currently employed. We called one of these a traditional system which represents a well-managed traditional bull beef enterprise and the other a Technosystem, a commercially available livestock finishing system developed and marketed by Kiwitech. The traditional system runs a stocking rate of 2.5 bulls per hectare. Bulls are purchased in the autumn are set-stocked or shuffle-grazed. Generally, early winter liveweight gains are reasonable but once pasture cover is eaten down liveweight gain declines. At this moderate stocking rate the bulls perform well through mid-spring but feed quality begins to decrease and inhibit performance in late spring. Typically under this scenario paddocks are in the size range of 8-10 ha.

To intensify subdivision a farmer could subdivide paddocks in half or in quarters with permanent electric fencing and permanently placed water. However, the cost is similar to a Technosystem at $\$ 300 /$ ha. This study therefore, only considers the Technosystem option as it provides 10 times the subdivision intensity at a similar cost. Users of the Technosystem believe that this intensive subdivision and the associated consistency in nutritional levels reduce livestock stress and leads to better meat conversion. They also consider that the ability to control post-grazing residuals leads to better pasture growth and pasture utilisation. This allows the system to move to a new level of stocking rate.

\section{Method}

The livestock policy chosen for both systems involved purchasing rising two-year bulls during autumn and sold them the following spring and summer. A set of 
parameters describing the expected performance of such a policy on the two finishing systems was sent to six local farmers with Technosystems, who had previously converted from either a standard or a square paddock intensification system, and to local consultants for comment. The parameters adopted in this paper are from feedback given by this group based on their experiences with converting to Technosystems. This was incorporated into a spreadsheet set up to calculate the gross margin before interest, return on capital, gross margin net of interest, and marginal return on extra capital invested. This would represent the common method of financial planning and analysis. It incorporates neither climatic or market variability but rather uses prices and productivity that farmers are comfortable with in the medium term.

The analysis highlights the significant proportion of the cost of intensification associated with more livestock in a more highly stocked system. At the Technosystem stocking rate, the additional livestock at current prices on our 100 ha model, cost $\$ 78000$ more than the standard stock system. Other costs are extra fencing and water supply at $\$ 35000$.

\section{Analysis of risk on profitability}

To assess the effects of climatic and market risks on the average financial situation described in Table 1, we modelled both systems using Stockpol (Marshall et al. 1991). This model is a decision support tool for livestock farmers that can estimate the effect on stock performance to changes in the major system parameters. To ensure that stock in the Technosystem performed more efficiently, reflecting user claims of lower stress levels than those in traditional systems, the mature weight was adjusted upwards by $10 \%$ using the "adjustments" feature. This, in effect reduces maintenance requirements by approximately $5 \%$. Intakes required for maximum growth are approximately $15 \%$ less than for cattle under a traditional system.

Pasture growth from an Otane site (MAF trial site number NFH163/35/74) cut for 11 years was used to determine the variability that can be expected. These data were divided into three quartiles and the average of each quartile was used to develop a pasture growth curve to represent a Good, Okay and Poor year. Three models were developed using Stockpol to calculate the climatic effects on stock performance. Comparatively the Technosystem models needed to draft stock slightly earlier owing to the higher stocking rates causing pasture cover to fall below the cover required for optimum live stock growth. Technosystem models restored cover more rapidly at the pasture growth rates used and were able to buy stock earlier at lighter weights. The variation in
Table 1 Assumptions used in the comparison of traditional bull beef finishing with a Technosystem.

\begin{tabular}{|c|c|c|}
\hline & Traditional & Technosystem \\
\hline $\begin{array}{l}\text { Sales } \\
\text { Number } \\
\text { Carcass weight } \\
\$ / \text { kg (net of levies) } \\
\$ / \text { head }\end{array}$ & $\begin{array}{r}250 \\
305 \\
2.51 \\
765\end{array}$ & $\begin{array}{r}422 \\
300 \\
2.50 \\
752\end{array}$ \\
\hline Total & $\$ 191250$ & $\$ 317560$ \\
\hline $\begin{array}{l}\text { Purchases } \\
\text { Number } \\
\text { Liveweight } \\
\$ / \text { kg } \\
\text { \$/head }\end{array}$ & $\begin{array}{r}252 \\
390 \\
1.27 \\
496\end{array}$ & $\begin{array}{r}424 \\
370 \\
1.28 \\
473\end{array}$ \\
\hline Total & $\$ 125000$ & $\$ 200550$ \\
\hline Gross income net of purchases & $\$ 66250$ & $\$ 117010$ \\
\hline $\begin{array}{l}\text { Direct costs } \\
\text { Animal health } \\
\text { Freight } \\
\text { Labour } \\
\text { Fertiliser } \\
\text { Fence and water repairs \& } \\
\text { maintenance }\end{array}$ & $\begin{array}{l}1260 \\
3750 \\
4500 \\
4460 \\
\\
1000\end{array}$ & $\begin{array}{r}2120 \\
6330 \\
10500 \\
9630 \\
\\
3000\end{array}$ \\
\hline Total direct costs & $\$ 14970$ & $\$ 31580$ \\
\hline $\begin{array}{l}\text { Gross margin before interest } \\
\text { Interest on extra borrowings } \\
\text { Fixed overheads (rates, } \\
\text { administration, insurance) }\end{array}$ & $\begin{array}{r}\$ 51280 \\
0 \\
25000\end{array}$ & $\begin{array}{r}\$ 85430 \\
9020 \\
25000\end{array}$ \\
\hline $\begin{array}{l}\text { Cash surplus (net of interest \& } \\
\text { overheads) }\end{array}$ & $\$ 26280$ & $\$ 51410$ \\
\hline Improvement on traditional system & & \\
\hline $\begin{array}{l}\text { Capital invested } \\
\text { Stock } \\
\text { Extra fencing and water } \\
\text { Land value }\end{array}$ & $\begin{array}{l}126360 \\
400000\end{array}$ & $\begin{array}{r}204060 \\
35000 \\
400000\end{array}$ \\
\hline $\begin{array}{l}\text { Total capital } \\
\text { Return on capital including } \\
\text { labour (\%) }\end{array}$ & $\begin{array}{r}\$ 526360 \\
4.9\end{array}$ & $\begin{array}{r}\$ 639060 \\
8.0\end{array}$ \\
\hline $\begin{array}{l}\text { Productions statistics } \\
\text { Margin per bull i.e., sales (less } \\
\text { death) - purchases }(\$ / \text { head) }\end{array}$ & 265 & 277 \\
\hline $\begin{array}{l}\text { Gross return per kg carcass } \\
\text { gained }(\$ / \mathrm{kg}) \\
\text { Carcass production/ha }(\mathrm{kg} / \mathrm{ha})\end{array}$ & $\begin{array}{r}2.46 \\
275\end{array}$ & $\begin{array}{r}2.43 \\
483\end{array}$ \\
\hline
\end{tabular}

Table 2 Key parameters used for the two models.

\begin{tabular}{lrr}
\hline & Traditional & Technosystem \\
\hline Pasture consumed (tonnes of dry & & \\
$\quad$ matter/ha) & 7.2 & 9.7 \\
Carcass production $(\mathrm{kg} / \mathrm{ha})$ & 275 & 483 \\
Weight $(\mathrm{kg})$ of dry matter eaten/kg of & & \\
$\quad$ carcass weight produced & 26.2 & 20.0 \\
Bulls/ha & 2.5 & 4.2 \\
Pasture utilisation & $83 \%$ & $90 \%$ \\
\hline
\end{tabular}

weights and pasture growth for each year-type is given in Table 3 and more detail of the Okay year is referred to in Table 1. 
Table 3 Carcass weights and stock values estimated by Stockpol from changes in pasture growth caused by climatic variation.

\begin{tabular}{lcccccc}
\hline & \multicolumn{1}{l}{ - } & & & \\
& Traditional & Techosystem & Traditional & Techosystem & Traditional & Techosystem \\
\hline Pasture growth (tonnes of dry matter/ha) & 11.5 & 15.0 & 9 & 11.8 & 6.8 & 8.9 \\
Carcass weight (kg/head) & 334 & 331 & 305 & 300 & 289 & 263 \\
Value (\$/head) & 841 & 831 & 765 & 752 & 719 & 651 \\
\hline
\end{tabular}

Table 4 Effect on cash surplus of climate and price variability compared with average budgeting.

\begin{tabular}{lrr}
\hline & Traditional & Technosystem \\
\hline Budget using average parameters & 26280 & 51410 \\
Mean of 150 ten-year simulations & & \\
$\quad$ incorporating variability & 27340 & 47990 \\
CV (one standard deviation)\% & 126 & 95 \\
Change in cash surplus from average & $4 \%$ & $(7 \%)$ \\
\hline
\end{tabular}

The Stockpol information was used to develop a simulation model using RANGEPACK HerdEconNZ (Stafford Smith \& Foran 1990). This program was set up to generate cashflows over a 10 -year period. To assess whether developing a Technosystem increased the variability in cash surpluses we ran the model firstly for the traditional bull beef system. We then compared this with developing the traditional system into a Technosystem. RANGEPACK used the financial parameters for the direct costs i.e., fixed overheads and capital development shown in Table 1. The transition from a traditional system to a Technosystem occurred over 1 year with all fencing and additional fertiliser being applied during the spring and summer with extra bulls purchased in autumn to give a total of 420 bulls by June 30 .

The 10-year simulations incorporated the effect of climatic variability by randomly selecting the performances of the three year-types shown in Table 3 . To take into account the effect of fluctuation in beef prices the model also randomly chose beef prices paid by meat processors (net of levies) of $\$ 3.00 / \mathrm{kg}, \$ 2.50 /$ $\mathrm{kg}$ and $\$ 2.00 / \mathrm{kg}$ of carcass weight. Simulations $(\mathrm{n}=150)$ were randomly generated and the model was set up to report the net worth and the cash surplus. The net worth was chosen to show if a farmer would improve wealth by intensifying the bull beef system. The cash surplus was used to assess whether the intensification increased the variability in annual returns. Net worth was made up of the post-tax profit and the added value of increased livestock numbers. The cash surplus was the gross income less direct costs, fixed overheads and interest.

Also analysed, was the effect different final stocking rates would have on a farmer's ability to increase net worth compared to the Traditional system. Stocking
Table 5 Effect of variation in price, climate and both price and climate on net worth at year 10 .

\begin{tabular}{lcccc}
\hline & $\begin{array}{c}\text { No } \\
\text { variation }\end{array}$ & $\begin{array}{c}\text { Price } \\
\text { variation }\end{array}$ & $\begin{array}{c}\text { Climate } \\
\text { variation }\end{array}$ & $\begin{array}{r}\text { Price and } \\
\text { climate } \\
\text { variation }\end{array}$ \\
\hline $\begin{array}{l}10 \text { year net worth } \\
\text { (000s) }\end{array}$ & 383 & 347 & 367 & 332 \\
$\begin{array}{c}\text { Change from average } \\
\text { parameters }\end{array}$ & 0 & $(9.3 \%)$ & $(4.1 \%)$ & $(13.4 \%)$ \\
\hline
\end{tabular}

rates assessed ranged from 300 to 500 bulls at increments of 50 .

Finally, we isolated the effects of variability on climate and price to assess their relative contributions in reducing net worth; comparing simulations that included (1) climate- and price-variability with models that had (2) price-variability only, (3) climate-variability alone and (4) no-variability.

\section{Results and discussion}

The first part of our analysis was to compare how well the method of preparing budgets using average figures compares with the more detailed simulations we have performed to incorporate climate and price variability. The analysis found that the simulated cash surpluses had a high variability. Developing a Technosystem reduces this variability with the coefficient of variation of one standard deviation reducing from $126 \%$ to $95 \%$. The decrease in variability associated with developing a Technosystem can probably be explained by lower ratio of farm expenditure to gross income in the Technosystem (63\%) versus the Traditional System $(76 \%)$. This would cause the same level of variability to have a greater effect on how much the cash surplus moves about the mean.

When we incorporated variability, the mean cash surplus of the Technosystem simulations decreased by $7 \%$ on the cash surplus we expected from average parameter budgeting. Interestingly, the traditional system improved by $4 \%$. The traditional system was set up to have no debt, therefore borrowing was increased to develop the Technosystem. Given the effect of a 95\% variability in cash surplus, some simulations, with particularly adverse price and climate sequences, 
will have negative cash surplus years increasing the amount needed to be borrowed. It is this indebtedness that reduces the simulated cash surplus below that of budgets prepared from average parameters.

\section{Effect of climate and price variability on net worth}

The average net worth of the 150 simulations showed that in moving from a traditional finishing system to a Technosystem a farmer was better off after $3 \frac{1}{2}$ years (Figure 1).

Figure 1 A comparison of the net worth over a ten-year period of two systems, one converting from a traditional beef finishing enterprise to a Technosystem, the other remaining as a traditional finishing system.

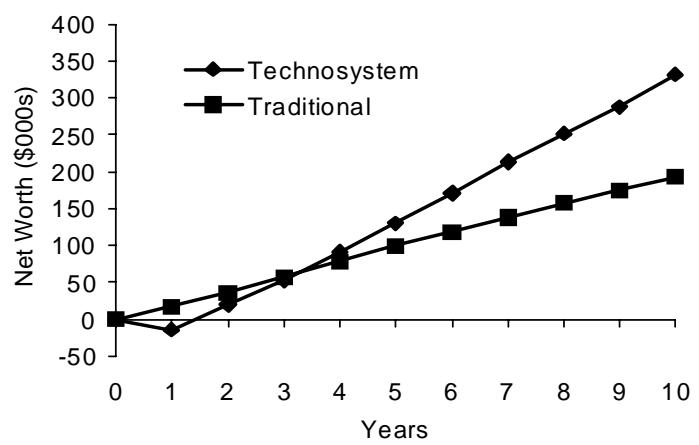

The average net worth for the Technosystem at year 10 was $\$ 331716$ (S.D. \$143 990) compared with the Traditional system of $\$ 192454$ (S.D. \$91 086) (Figure 2).

Figure 2 The range of net worths at year 10 from 150 simulations for a Traditional bull system running 250 bulls on 100 hectares, and intensifying using a Technosystem to run 424 bulls on the same area at a cost of $\$ 350 / \mathrm{ha}$.



Of the 150 simulations, $84.7 \%$ of runs achieved a higher net worth than the mean risk-adjusted net worth of the traditional system at year 10. In simulations that failed to generate higher net worth, very adverse combinations of price and climate were experienced during the development period.

\section{Effect of final productivity on achieving a greater net worth}

High probabilities (greater than $80 \%$ ) of gaining a net worth better than the traditional system depend on achieving a final stocking rate of 400 bulls or better. On the model farm of 100 hectares this equates to 4 bulls per hectare, or a marginal increase from the Traditional system of 1.5 bulls per hectare. If final stocking rates are only 3.5 bulls per hectare, then the probability drops to $58 \%$ (Figure 3 ).

Figure 3 The probability that the net worth at year 10 will be greater than the Traditional system if development increases total stocking rates.

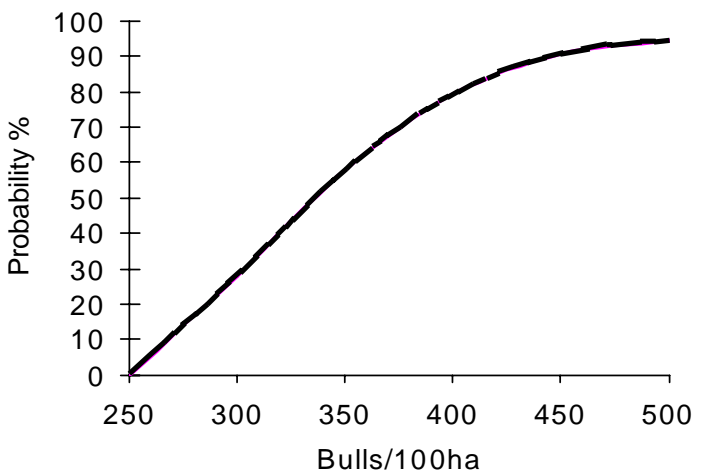

\section{Contribution of price and climate variability to net worth}

Climatic and price variability contributed to moderate variation in the average situation shown in Figure 1. Most of the reduction in net worth was caused by price variation, however the effects of price and climate variation were cumulative. The total reduction in net worth caused by both forms of variation was $13.4 \%$.

While this does not seem large, at year 10 it will have eroded $28 \%$ of the gains in net worth that a farmer would have expected from making the change to a Technosystem if they have used average parameters.

\section{Conclusion}

Feedback from local growers indicated significant improvement in stocking rates under a Technosystem. We did not establish how this occurred - whether it is 
better forage growth, more efficient stock or better utilisation of pasture. In fact we needed to incorporate all of these for our Stockpol model of a traditional system to be feasible, once bull numbers were increased from 250 to 424 .

Intensification, as we have described it, should result in improved cash surpluses and net worth for beef farmers provided they achieve final stocking rates of 4 bulls per hectare, or a marginal increase of 1.5 bulls per hectare. This is still true when we consider the impact of variability on the development of a Technosystem. The likelihood of climate and price fluctuations causing a Technosystem to achieve less than the traditional system was low. An unexpected outcome was a reduction in the variability in cash surpluses with development, and we have offered the explanation that development in this case enabled costs to be better covered by proportionally more revenue than in the traditional system.

Variability in price and climate disturbed cashflow significantly enough to reduce overall profitability. The magnitude of this disturbance was $13.4 \%$ of the accumulated profit at year 10. Markets, rather than climate caused the majority of this. The overall effect was not high but if a farmer had used average parameters in planning, then variability will wipe out $28 \%$ of the returns that were expected over and above the traditional system. This should be a cautionary note for forecasting with average production and price parameters for medium-term planning. In general, we feel the projections suggested the intensification options would provide very good returns on investment and while risks are relatively significant, the likelihood of being worse off post-development are low.

\section{REFERENCES}

Marshall, P.R; McCall, D.G.; Johns, K.L. 1991. Stockpol: A decision support model for livestock farms. Proceedings of the New Zealand Grassland Association 53: 137-140.

Stafford-Smith, D.M.; Foran, B.D. 1988. Strategic decisions in pastoral management. Australian Rangelands Journal 10: 82-95. 
